\title{
Pre-Concentration and Determination of Molybdenum in the Rouge River, Michigan, USA, with Graphite Furnace Atomic Absorption Spectrometry
}

\author{
Ali Bazzi ${ }^{1} \&$ Bo Ra Ye ${ }^{1}$ \\ ${ }^{1}$ Department of Natural Sciences, University of Michigan-Dearborn, Dearborn, USA \\ Correspondence: Ali Bazzi, Department of Natural Sciences, University of Michigan-Dearborn, Dearborn, \\ Michigan 48128-1491, USA. Tel: 1-313-593-5367. E-mail: abazz@umd.umich.edu
}

Received: October 25, 2012 Accepted: November 5, 2012 Online Published: November 22, 2012

doi:10.5539/ijc.v4n6p54

URL: http://dx.doi.org/10.5539/ijc.v4n6p54

\begin{abstract}
Molybdenum is an essential element to humans because of its role in several enzymes, and its occurrence in natural waters is of significance from environmental and biochemical standpoints. Owing to the low concentration of molybdenum in natural waters, pre-concentration is required prior to its determination with atomic spectroscopic techniques. This paper reports on the pre-concentration and determination of molybdenum in the Rouge River, Michigan, USA with graphite furnace atomic absorption spectrometry (GFAAS). Sample preparation and pre-concentration were performed using ultra-trace analysis methodology in a class 100 clean room laboratory. The molybdenum was pre-concentrated on a Bio-Rad Chelex ${ }^{\circledR} 100$ resin, followed by elution from the resin with ammonia solution. Subsequently, the single-point standard addition method was used, and the absorbance owing to molybdenum was measured at $313.3 \mathrm{~nm}$. An overall concentration factor of ten was realized for the final pre-concentrated volume, and the results from several sampling locations on the four branches of the Rouge River yielded molybdenum concentrations ranging from 1.98 to $4.21 \mu \mathrm{g} \cdot \mathrm{L}^{-1}$ with an overall average of $2.94 \mu \mathrm{g} \mathrm{L}^{-1}$. The precision of the results, based on quintuplet determinations from each sampling site, varied between 6.1 to $8.8 \%$ relative standard deviation (\%RSD). Although the concentration of molybdenum in the Rouge River is in line with the lower reported molybdenum levels in the US and world rivers, it is higher than the level that arises from natural sources only and therefore has anthropogenic causes.
\end{abstract}

Keywords: molybdenum, atomic absorption spectrometry, ultra-trace methodology, standard addition, chelating resin, Rouge River, pre-concentration

\section{Introduction}

Molybdenum is present predominantly in the VI oxidation state as $\mathrm{MoO}_{4}{ }^{2-}$ in seawater, tap water, and river water ( $\mathrm{Du}, \mathrm{Li}$, Yang, \& Lu, 2003). Its occurrence in water is of importance from environmental and biochemical viewpoints owing to its bio-essential nature (Sun, Yang, \& Tzeng, 1999). Molybdenum is a micronutrient vital to plant growth (Zimmer \& Mendel, 1999), and animals (Hall, 2012).Additionally, it is considered an important element for humans owing to its role in the function of three enzymes: aldehyde oxidase, xanthine oxidase, and sulfite oxidase (Turnlund, Keyes, Peiffer, \& Chiang, 1995; Goldhaber, 2003; Pyrzynska, 2007). The recommended daily allowance for molybdenum is $34 \mu \mathrm{g} \cdot \mathrm{day}^{-1}$ for adult men and women (Institute of Medicine of the National Academies, 2012). The toxicity of molybdenum has been observed in humans, and USEPA has set its reference dose (RfD) at $0.005 \mathrm{mg} / \mathrm{kg}$-day (Goldhaber, 2003). Animal studies have linked high intakes of dietary molybdenum with kidney failure (Goldhaber, 2003), weight loss, anorexia, reduced fertility, and premature death (Smedley, Cooper, Lapworth, \& Ander, 2008). Molybdenum is extensively used in many industrial processes which can increase the amount of this element that is released into the environment (Ghiasvand, Shadabi, Mohagheghzadeh, \& Hashemi, 2005). Since molybdenum is an essential trace element for plants, animals, and humans, the monitoring of molybdenum in environmental samples is desirable and highly recommended (Pyrzynska, 2007).

The direct determination of molybdenum in natural water with flame atomic absorption spectrometry (FAAS), graphite furnace atomic absorption spectrometry (GFAAS) and inductively coupled plasma optical emission spectroscopy (ICP-OES) is difficult and challenging because of its low concentration and/or matrix interferences 
(Sabarudin, Oshima, Noguchi, \& Motomizu, 2007; Ferreira, dos Santos, \& Campos, 2003). Specifically, in the determination of molybdenum in natural water with GFAAS, the reproducibility of the data declines as the concentration of molybdenum reaches levels at or below $1 \mu \mathrm{g} \mathrm{L} \mathrm{L}^{-1}$. Values of \%relative standard deviation (\%RSD) of $25 \%$ and $58 \%$ have been reported at molybdenum concentrations of $1.2 \mu \mathrm{g} \mathrm{L}^{-1}$ and $0.6 \mu \mathrm{g} \mathrm{L}^{-1}$, respectively (Johannesson, Lyons, Graham, \& Welch, 2000; Jones \& McLain, 1997). Therefore, pre-concentration is essential when analyzing natural water samples for molybdenum at very low concentrations. The use of chelating resins to concentrate trace elements, including molybdenum, from natural water samples has been reported (Riley \& Taylor, 1968a;1968b; Wang \& Sañudo-Wilhelmy, 2008; Sung, Liu, \& Huang, 1997; Huang, Lai, \& Shih, 1995; Greenberg \& Kingston, 1983). In addition to chelating resins, several other approaches to pre-concentrate molybdenum from water samples have been reported. The reported studies include the sorption of molybdate (VI) thiocyanate complex onto polyurethane foam prior to its elution and determination by GFAAS (Ferreira, dos Santos, \& Campos, 2003), pre-concentration using microcrystalline triphenylmethane, maghemite nanoparticles and ionic liquid-based dispersive liquid-liquid micro-extraction before spectrophotometric determination ( $\mathrm{Li}$, Zhao, Guan, \& Liu, 2006; Afkhami, \& Norooz-Asi, 2009; Gharehbaghi \& Shemirani, 2011) and biosorption on immobilized yeasts ahead of ICP-OES quantification (Gil et al., 2007).

In all of the aforementioned studies, normal laboratory environment and ordinary equipment cleaning and decontamination procedures have been employed. In this paper, we report on the pre-concentration of molybdenum from the Rouge River, USA, with Chelex ${ }^{\circledR} 100$ followed by its determination with GFAAS. Molybdenum pre-concentration and preparation of samples for analysis were carried out using ultra-trace analysis methodology in a class 100 clean room laboratory. All polyethylene laboratory ware used for sampling, storing, and preparing the Rouge River water samples for analysis were cleaned and decontaminated using a protocol for minimizing contamination in the analysis of trace metals in natural waters (Nriagu, Lawson, Wong, \& Azcue, 1993). The use of this decontamination protocol has also been reported in the determination and speciation of copper in Saginaw Bay, Lake Huron (Bazzi et al., 2002) and in the analysis of biological samples for trace metals (Bazzi, Nriagu, Inhorn, \& Linder, 2005; Bazzi, Nriagu, \& Linder, 2008)

The Rouge River is located in southeastern Michigan, USA, with a drainage basin that includes portions of several counties in the Detroit Metropolitan area. The Rouge River is one of United States Environmental Protection Agency (USEPA) areas of concern in the Great Lakes region. The Rouge River has four main branches: Upper, Main, Middle, and Lower Rouge rivers totaling 125 miles of water ways that primarily flow through Wayne and Oakland counties in the Detroit Metropolitan area, with some headwaters in Washtenaw County (United States Environmental Protection Agency, USEPA, 2012). The four branches flow in a southeast direction and link with the Detroit River south of the City of Detroit. Water samples taken from the four branch sites of the Rouge River in 2007 and 2008 were pre-concentrated and analyzed for molybdenum with GFAAS. The concentration of molybdenum in the Rouge River is compared with the molybdenum levels of world and United States Rivers.

\section{Experimental}

\subsection{Clean Room Laboratory}

Sample filtration, pre-concentration, and treatment were carried out in a class 100 clean room.

\subsection{Equipment Cleaning and Decontamination}

Equipment used for sampling, storing, and preparing the Rouge River water samples for analysis were cleaned and decontaminated using a protocol for ultra-trace analysis (Nriagu et al., 1993).

\subsection{Instrumentation}

Atomic Absorption Spectrometer Varian SpectrAA600 equipped with a graphite furnace tube analyzer (GTA100) was used to measure the absorbance of molybdenum at the $313.3 \mathrm{~nm}$ resonance line. A pre-set graphite furnace atomization program with a $2800{ }^{\circ} \mathrm{C}$ maximum atomization temperature was used.

\subsection{Chemical Reagents and Solutions}

Milli-Q water, high purity nitric acid (Optima-Fisher Scientific and Sigma-Aldrich), and 25\% ammonia (99.99\%, Alfa Aesar) were used in the sample treatment and preparation. Ammonium molybdate, $(99.98 \%$, Aldrich) was used to prepare the stock molybdenum solution. Bio-Rad Chelex ${ }^{\circledR} 100$ (50-100 mesh) resin in the sodium form was converted to the hydrogen form using $2.0 \mathrm{M}$ high purity nitric acid solution and was used to pre-concentrate molybdenum from the Rouge River water samples. The 2.0 M nitric acid, $0.20 \mathrm{M}$ nitric acid, and 4.0 M ammonia solutions were prepared from the high purity concentrated reagents and Milli-Q water. The working standard molybdenum solution $\left(1.008 \mu \mathrm{g} \cdot \mathrm{mL}^{-1}\right)$ was prepared by successive dilution from the molybdenum stock solution 


\section{$\left(1008 \mu \mathrm{g} \cdot \mathrm{mL}^{-1}\right)$.}

\subsection{Sample Collection, Filtration and Processing}

A custom made all-Teflon ${ }^{\circledR}$ sampling arm was used for sampling from the river bank. The Rouge River water samples were collected in March, August, and September 2007 and July, August, and September 2008. The high density polyethylene (HDPE) bottles used for sample collection were filled in the laboratory with $0.20 \mathrm{M}$ high purity nitric acid and triple bagged before transporting to the sampling location. Powder free polyethylene gloves were worn while sampling. The HDPE bottles were rinsed on site with Milli-Q water and river water before securing the water sample. After sample collection, the HDPE bottles containing the water samples were triple-bagged at the site and placed in a cooler for transport to the clean room laboratory. The water samples were vacuum filtered within 24 hours of sample collection using a Whatman $45 \mu \mathrm{m}$ nylon membrane. Approximately the first $100 \mathrm{~mL}$ of each filtered bottle was discarded. The filtered samples were stored at $4{ }^{\circ} \mathrm{C}$ until $\mathrm{pH}$ adjustment and pre-concentration.

\subsection{Resin Form Conversion and Column Preparation}

Eight $3.00 \mathrm{~g}$ samples of Chelex ${ }^{\circledR} 100$ resin (in the sodium form) were transferred into eight polyethylene labeled beakers. Five of the Chelex ${ }^{\circledR} 100$ resin samples were used to pre-concentrate the molybdenum from the Rouge River samples, while the remaining three served to prepare blank trials. The Chelex® 100 resin was converted into the hydrogen form by adding $10 \mathrm{~mL}$ of $2.0 \mathrm{M}$ high purity nitric acid to each resin sample and leaving the acid in contact with the resin for 15 minutes. This was followed by pouring the slurry into a Bio-Rad polypropylene column equipped with a stopcock and adjusting the flow rate to $2.0 \mathrm{~mL}$ per minute. To ensure complete conversion of the Chelex ${ }^{\circledR} 100$ resin to the hydrogen form, $20 \mathrm{~mL}$ of $2.0 \mathrm{M}$ high purity nitric acid were run through the polypropylene column containing the resin while maintaining the flow rate at $2.0 \mathrm{~mL}$ per minute. Finally, the resin was washed with Milli-Q water until the $\mathrm{pH}$ of the effluent reached 5 to 5.2 . During the washing step, the rate may be increased to about $5.0 \mathrm{~mL}$ per minute.

\subsection{Pre-Concentration and Elution of Molybdenum}

Five $500 \mathrm{mLsamples}$ of the filtered Rouge River water, after adjustment to $\mathrm{pH}=5.0$ with ultra-pure $0.20 \mathrm{M}$ nitric acid, were passed through their respective Bio-Rad polypropylene columns containing the Chelex ${ }^{\circledR}$ resin at a flow rate of $5 \mathrm{~mL}$ per minute. Each Bio-Rad polypropylene column was equipped with a stopcock and a plastic reservoir to accommodate the water sample. Subsequently, the column was rinsed three times with $5 \mathrm{~mL}$ aliquots of Milli-Q water. The effluents from these two previous steps were discarded. Next, each resin was eluted with $20.00 \mathrm{~mL}$ of $4.0 \mathrm{M}$ ammonia at a flow rate of $2.0 \mathrm{~mL}$ per minute to remove the retained molybdate. The effluent was collected in a polyethylene beaker. Afterward, each column was rinsed twice with $5.00 \mathrm{~mL}$ aliquots of Milli-Q water and the water was collected in each respective beaker. The content of each beaker was analytically transferred to a $50 \mathrm{~mL}$ volumetric flask and diluted to the mark with Milli-Q water. Three $500 \mathrm{~mL}$ aliquots of Milli-Q water, after adjustment to $\mathrm{pH}=5.0$, served as the blank trials and were treated as above.

\subsection{Preparation of Single-Point Standard Addition Solutions}

Five single-point standard addition solution sets corresponding to the five Rouge River pre-concentrated samples were prepared. To prepare the standard addition solutions, aliquots of $20.00 \mathrm{~mL}$ from each of the eluted water samples were transferred into two $25 \mathrm{~mL}$ volumetric flasks. This was followed by the addition of 0 and $1.00 \mathrm{~mL}$ of the $1.008 \mu \mathrm{g} \mathrm{Mo} \mathrm{mL}{ }^{-1}$ working standard molybdenum solution to the first and second flasks, respectively. In addition, three aliquots of $20.00 \mathrm{~mL}$ of the eluted blank trials were transferred into three $25 \mathrm{~mL}$ flasks. All solutions in the $25 \mathrm{~mL}$ flasks were diluted to the mark with Milli-Q water and inverted to mix. In total, five sets of standard addition solutions and one set of three blank solutions were prepared for each sampling site.

\subsection{Graphite Furnace Atomic Absorption Measurement}

The blank and sample solutions were injected into the graphite tube and the atomization and measurement followed a preset program with a maximum atomization temperature of $2800{ }^{\circ} \mathrm{C}$. The injected sample size was $10.0 \mu \mathrm{L}$.

The general methodology followed for sample pre-concentration and measurements is presented in Figure 1. 


\section{Sample: Filter $500 \mathrm{~mL}$ Rouge River water and adjust to $\mathrm{pH}=\mathbf{5 . 0}$ (quintuplet).}

$$
\begin{aligned}
& \text { Blank: Filter } 500 \mathrm{~mL} \\
& \text { MilliQwater and adjust } \\
& \text { topH }=5.0 \text { (triplicate). }
\end{aligned}
$$

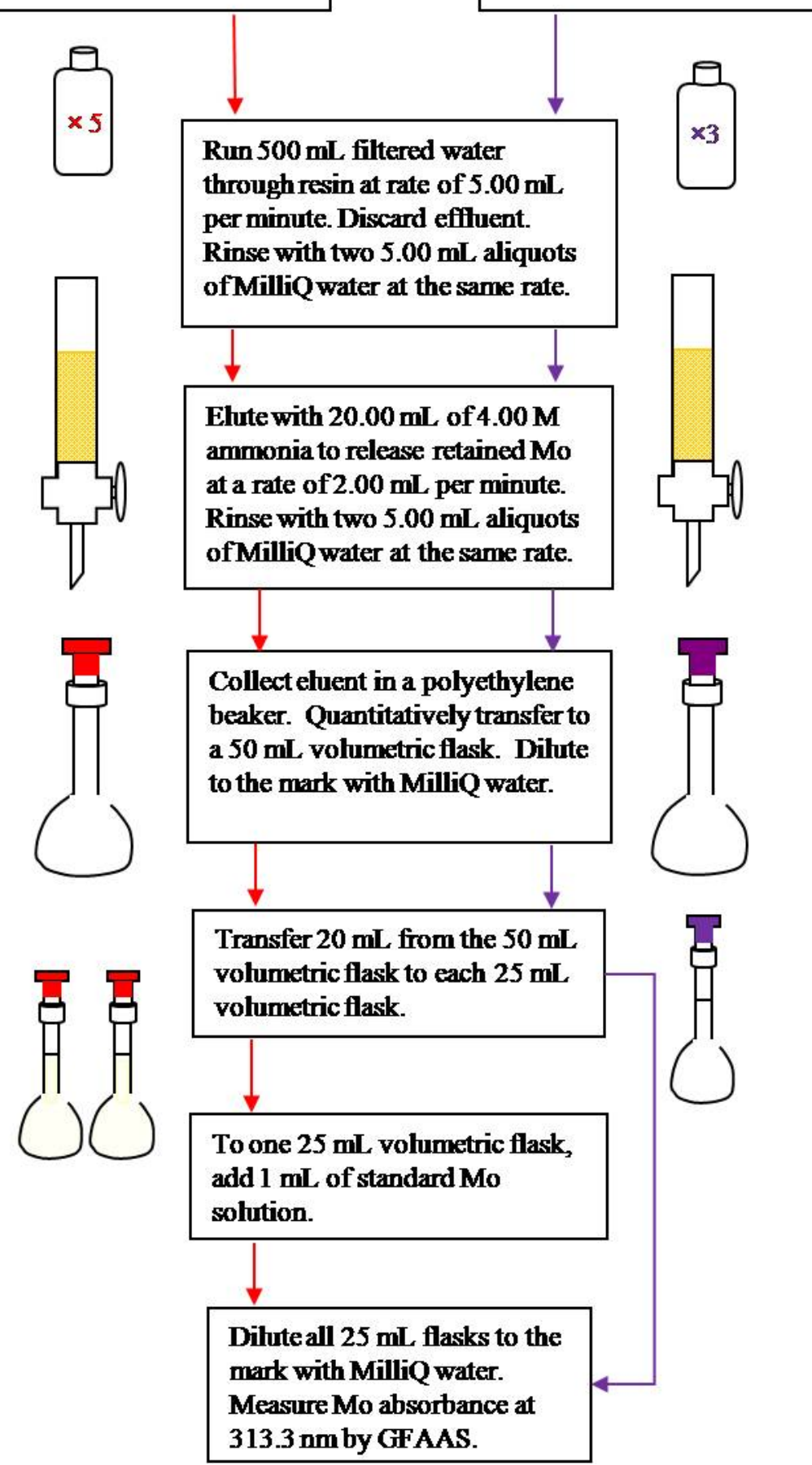

Figure 1. General methodology for the pre-concentration and determination of molybdenum in the Rouge River with GFAAS

\section{Results and Discussion}

Although GFAAS is a highly sensitive atomic spectroscopic technique, pre-concentration is required in order to determine molybdenum in the Rouge River with GFAAS with an acceptable level of confidence. The reproduciblity of the data obtained when using GFAAS for the determination of molybdenum in natural waters 
has been shown to deteriorate drastically as the concentration of molybdenum approaches the $1 \mu \mathrm{g} \cdot \mathrm{L}^{-1}$ level and lower (Johannesson et al., 2000; Jones et al., 1997). Owing to the low level of molybdenum in the Rouge River, Chelex ${ }^{\circledR} 100$ (50-100 mesh) resin was used to preconcentrate molybdenum. Since a major concern when conducting trace-metal analysis in natural waters is the contamination associated with sampling and handling of the water samples, a multistep sequence of decontamination and cleaning process for laboratory ware was followed to avoid high blanks and improve the quality of the analytical results (Nriagu et al., 1993). Metal-free conditions were maintained during the Rouge River water sampling by employing an all-Teflon ${ }^{\circledR}$ custom-made sampling arm and HDPE bottles for sample collection and storage. Additionally, sample pre-concentration and preparation of the Rouge River water samples for analysis were carried out in a class 100 clean room laboratory. The $\mathrm{pH}$ adjustment to 5.0 prior to pre-concentration with Chelex ${ }^{\circledR} 100$ resin was necessary. This optimal $\mathrm{pH}$ condition yielding $100 \%$ recovery was previously reported for the pre-concentration of molybdenum from sea water (Riley et al., 1968a; 1968b) and was confirmed in our laboratory for the Rouge River analysis. An overall concentration factor of ten was achieved in the $50 \mathrm{~mL}$ final volume as a result of the pre-concentration step. The single-point standard addition method was used to analyze the pre-concentrated water samples with GFAAS.

The mean concentrations of molybdenum and the \%RSDs from all sampling sites of the four branches of the Rouge River are presented in Tables 1 and 2 . The \%RSDs of the analysis of the seven quintiplet sets ranged from $6.1 \%$ to $8.8 \%$.

Table 1. Concentration $\mu \mathrm{g} M \mathrm{~L}^{-1}$ in the Rouge River, 2007 samples

\begin{tabular}{ccccc}
\hline Branch/Tributary & Main Rouge & Main Rouge & Lower Rouge & $\begin{array}{c}\text { Middle } \\
\text { Rouge }\end{array}$ \\
& Sample Location & UM-Dearborn/Henry Ford & EM-Dearborn/Henry Ford & Ford Field \\
Park & Hines Drive \\
Sampling Date & March 2007 & Estate & September & $\begin{array}{c}\text { September } \\
2007\end{array}$ \\
\hline 1 & 2.37 & August 2007 & 2007 & 2.33 \\
2 & 2.06 & 2.19 & 3.41 & 2.64 \\
3 & 2.01 & 1.95 & 3.77 & 2.92 \\
4 & 1.90 & 1.91 & 3.55 & 2.75 \\
5 & 2.18 & 1.97 & 3.23 & 2.76 \\
Average & 2.10 & 1.89 & 3.11 & 2.68 \\
Std. Dev. & 0.18 & 1.98 & 3.41 & 0.22 \\
\%RSD & 8.4 & 0.12 & 0.26 & 8.2 \\
\hline
\end{tabular}

Table 2. Concentration, $\mu \mathrm{g} M \mathrm{Mo}^{-1}$, in the Rouge River, 2008 samples

\begin{tabular}{cccc}
\hline $\begin{array}{c}\text { Branch/Tributary } \\
\text { Sample Location } \\
\text { Sampling Date }\end{array}$ & $\begin{array}{c}\text { Middle Rouge } \\
\text { Hines Drive } \\
\text { July 2008 }\end{array}$ & $\begin{array}{c}\text { Lower Rouge } \\
\text { Ford Field Park } \\
\text { August 2008 }\end{array}$ & $\begin{array}{c}\text { Upper Rouge } \\
\text { Franklin and 14 mile } \\
\text { September 2008 }\end{array}$ \\
\hline 1 & 4.21 & 3.48 & 2.66 \\
2 & 4.06 & 3.14 & 2.68 \\
3 & 4.69 & 3.81 & 3.02 \\
4 & 4.09 & 3.20 & 2.48 \\
5 & 3.98 & 3.75 & 2.53 \\
Average & 4.21 & 3.48 & 2.67 \\
Std. Dev. & 0.28 & 0.30 & 0.21 \\
\%RSD & 6.7 & 8.8 & 7.9
\end{tabular}

The 2007 data given in Table 1 indicate that the lowest molybdenum concentration was found in the Main Rouge 
River branch (UM-D/Henry Ford Estate) and the highest was found in the Lower Rouge River branch (Ford Field Park). Also, Table 1 demonstrates that there was no significant difference in the level of molybdenum in the samples obtained from the Main Rouge River branch (UM-D/Henry Ford Estate) that were collected five months apart. Table 2 shows that the lowest concentration obtained in 2008 was that from the Upper Rouge branch. For the two locations that were sampled in 2007 and again in 2008 (Middle and Lower branches), the level of molybdenum in the Middle Rouge branch increased dramatically from 2.68 to $4.21 \mu \mathrm{g} \mathrm{Mo} \mathrm{L}^{-1}$, whereas the concentration of the Lower Rouge branch remained essentially unchanged. The highest values of molybdenum concentration were found in samples from the Lower Rouge (Ford Field Park) and Middle Rouge (Hines Park) sampling sites. Each of these sampling locations is downstream from a golf course located along the banks of the Middle and the Lower Rouge, respectively. The overall average concentration of molybdenum in the Rouge River from all sites over the two years was $2.94 \mu \mathrm{g} \mathrm{Mo}^{-1}$. Representative GFAAS data are shown in Table 3 for samples collected from the site located near the Henry Ford Estate on the University of Michigan-Dearborn campus.

Table 3. Representative GFAAS data for samples collected from the site located near the Henry Ford Estate on the University of Michigan-Dearborn campus. Lamp current $=7.0 \mathrm{~mA}$, slit width $=0.5 \mathrm{~nm}, \lambda=313.3 \mathrm{~nm}$

\begin{tabular}{cccc}
\hline Sample & $\begin{array}{c}\text { Absorbance* of the } \\
\text { unspiked aliquot }\end{array}$ & $\begin{array}{c}\text { Absorbance* of the } \\
\text { spiked aliquot }\end{array}$ & $\mu g$ Mo L ${ }^{-1}$ \\
\hline 1 & 0.089 & 0.294 & 2.19 \\
2 & 0.079 & 0.283 & 1.95 \\
3 & 0.076 & 0.277 & 1.91 \\
4 & 0.080 & 0.285 & 1.97 \\
5 & 0.077 & 0.282 & 1.89 \\
Average & 0.080 & 0.284 & 1.98 \\
\%RSD & 6.4 & 2.2 & 6.1 \\
\hline
\end{tabular}

* Each absorbance value is the average of the measured absorbancesof three $10.0 \mu \mathrm{L}$ injections.

A comparison of the Rouge River molybdenum concentration with the published levels of molybdenum in other United States and world rivers is provided in Table 4. Our mean concentration of $2.94 \mu \mathrm{g} \mathrm{Mo} \mathrm{L}^{-1}(\mathrm{n}=35)$ for the Rouge River is lower than the reported concentrations for the other US Rivers and many of the world rivers, some of which appear to be highly contaminated (Johannesson, Lyons, Graham, \& Welch, 2000; Neal \& Robson, 2000; Huang, Sillanpää, Duo, \& Gjessing, 2008; Pizarro, Vergara, Rodríguez, \& Valenzuela, 2010). Our average concentration is in line with the mean reported levels for the Aliakmonas and Pinios (Karamanis, Stamoulis, Ionndes, \& Patiris, 2008), and the Thames and Great Ouse (Neal \& Robson, 2000). However, our average molybdenum concentration is about three times the value reported for the Seine and more than four times that of the Marne (Elbaz-Poulichet, Seidel, Casiot, \& Tusseau-Vuillemin, 2006), and Asahi and Zasu (Sabarudin, Oshima, Noguchi, \& Motomizu, 2007). The average molybdenum Rouge River concentration is more than three times the values of the upper range of the Aare River (Neubert et al., 2011), and the lower range of the Chang Jiang River (Neubert et al., 2011), and it is also six times the concentrations of the lower ranges of Aare river and more than ten times the concentration of the upper range of the Kleine Emme rivers (Neubert et al., 2011). Even though the molybdenum concentration in the Rouge River tends to be in line with the lower reported levels of the US and world rivers, it is still higher than the concentration that arises from natural sources only and therefore has anthropogenic causes. One major reason is that the oldest and most heavily industrialized and populated area in southeast Michigan is located within the Rouge River Watershed (United States Environmental Protection Agency, USEPA, 2012). The "pre-anthropogenic" riverine molybdenum level has been estimated at 5

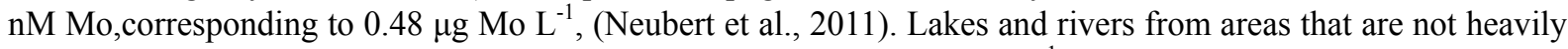
affected by anthropogenic contaminations generally have less than $1 \mu \mathrm{g} \mathrm{L}^{-1}$ of molybdenum (Hem, 2012). If we assume as reported in the literature that the pre-anthropogenic concentration in riverine water is $0.48 \mu \mathrm{g} \mathrm{L}^{-1}$, then the \%relative increase owing to anthropogenic sources in the Rouge is greater than 500\%. An important anthropogenic source of molybdenum to aquatic systems is the use of fertilizers containing molybdenum (Canadian Water Quality Guidelines for the Protection of Aquatic Life-Molybdenum, 1999). This source might also have contributed to the current level of molybdenum in the Rouge River through urban and agricultural 
runoffs.

Table 4. Comparison of the molybdenum concentration of $2.94 \mu \mathrm{g} \mathrm{L}^{-1}$ in the Rouge River to molybdenum levels in other United States and world rivers

\begin{tabular}{cccc}
\hline River & Country & Mo, $\mu \mathrm{g} \cdot \mathrm{L}^{-1}$ & Reference \\
\hline Kleine Emme & Switzerland & $0.19-0.28^{*}$ & Neubert et al., 2011 \\
Aare & Switzerland & $0.52-0.88^{*}$ & Neubert et al., 2011 \\
Marne & France & 0.68 & Elbaz-Poulichet et al., 2006 \\
Zasu & Japan & 0.84 & Sabarudin et al., 2007 \\
Asahi & Japan & 0.95 & Sabarudin et al., 2007 \\
Seine & France & 0.97 & Elbaz-Poulichet et al., 2006 \\
Chang Jiang & China & $0.86-1.25^{*}$ & Neubert et al.,2011 \\
Aliakmonas & Greece & 2.5 & Karamanis et al., 2008 \\
Thames & United Kingdom & 2.85 & Neal et al., 2000 \\
Rouge & United States & $\mathbf{2 . 9 4}$ & This study \\
Pinios & Greece & 3.3 & Karamanis et al., 2008 \\
Great Ouse & United Kingdom & 3.34 & Neal et al., 2000 \\
Trent & United Kingdom & 5.05 & Neal et al., 2000 \\
Aoos & Greece & 5.1 & Karamanis et al., 2008 \\
Indian & United States & 6.7 & Trocine \& Trefry, 1996 \\
Mississippi & United States & $1.11-6.78^{*}$ & Shiller, 1997 \\
Louros & Greece & 6.9 & Karamanis et al., 2008 \\
Rio Conchos & Mexico & $2.3-7.5$ & Gutiérrez \& Borrego, 1999 \\
San Joaquin & United States & $2.7-9.0$ & Leland \& Scudder, 1990 \\
Walker & United States & $1.23-9.70^{*}$ & Johannesson, et al., 2000 \\
Tista & India & $4.13-13.3^{*}$ & Neubert et al., 2011 \\
Mekong & China & $10.6-13.4$ & Huang et al., 2008 \\
Yangtze & China & $5.09-13.9$ & Huang et al., 2008 \\
Kalamas & Greece & 15.4 & Karamanis et al., 2008 \\
Yarlung Tsangpo & China & $5.15-17.2$ & Huang et al., 2008 \\
Salween & China & $4.5-20.1$ & Huang et al., 2008 \\
Aire & United Kingdom & 23.48 & Neal et al., 2000 \\
Truckee & United States & $1.10-57.6^{*}$ & Johannesson et al., 2000 \\
Carson & United States & $5.20-30.5^{*}$ & Johannesson et al., 2000 \\
Endorreicas & Chile & 60 & Pizarro et al., 2010 \\
Maipo & Chile & 463 & Pizarro et al., 2010 \\
\hline
\end{tabular}

* Reported values for molybdenum were given in $\mathrm{nM}$. These were converted to $\mu \mathrm{g} \mathrm{Mo} \mathrm{L}^{-1}$.

\section{Conclusion}

Ultra-trace analysis methodology and a clean room laboratory environment were used in the pre-concentration and determination of molybdenum in the Rouge River, Michigan, USA. GFAAS, in conjunction with the single-point standard addition method, was employed in the determination step with the absorbance of molybdenum measured at the $313.3 \mathrm{~nm}$ resonance line. A concentration factor of ten was realized as a result of the pre-concentration step. The overall average molybdenum concentration in the Rouge River was found to be $2.94 \mu \mathrm{g} \cdot \mathrm{L}^{-1}(\mathrm{n}=35)$ with \%RSD of the data ranging between 6.1 and $8.8 \%$ for individual sites. The mean concentration of molybdenum in the Rouge River is in line with the lower concentrations reported for world and 
US Rivers. However, the level of molybdenum in the Rouge River is higher than the concentration that arises from natural sources only, and therefore has anthropogenic causes that are inherent to its location in a heavily industrialized and highly populated area.

\section{Acknowlegements}

We acknowlege the Office of Sponsored Research at the University of Michigan-Dearborn for providing a summer scholarship stipend for Bo Ra Ye.

\section{References}

Afkhami, A., \& Norooz-Asi, R. (2009). Removal, preconcentration and determination of Mo(VI) from water and wastewater samples using maghemite nanoparticles. Colloids and Surfaces A: Physicochem. Eng. Aspects, 346, 52-57. http://dx.doi.org/10.1016/j.colsurfa.2009.05.024

Bazzi, A., Lehman, J. T., Nriagu, J. O., Hollandsworth, D., Irish, N., \& Nosher, T. (2002). J. Great Lakes Res., 28(3), 466-478. http://dx.doi.org/10.1016/S0380-1330(02)70598-4

Bazzi, A., Nriagu, J. O., \& Linder, A. M. (2008). Determination of toxic and essential elements in children's blood with inductively coupled plasma-mass spectrometry. J. Environ. Monit., 10, 1226-1232. http://dx.doi.org/10.1039/b809465a

Bazzi, A., Nriagu, J. O., Inhorn, M. C., \& Linder, A. M. (2005). Determination of antimony in human blood with inductively coupled plasma-mass spectrometry. J. Environ. Monit., 7, 1251-1254. http://dx.doi.org/10.1039/b510088g

Canadian Water Quality Guidelines for the Protection of Aquatic Life. (1999). Molybdenum. Retrieved from ceqg-rcqe.ccme.ca/download/en/195

Du, J., Li, J., Yang, L., \& Lu, J. (2003). Sensitive and selective determination of molybdenum by flow injection chemiluminescence method combined with controlled potential electrolysis technique. Anal. Chim. Acta, 481, 239-244. http://dx.doi.org/10.1016/S0003-2670(03)00083-7

Elbaz-Poulichet, F., Seidel, J-L., Casiot, C., \& Tusseau-Vuillemin, M-H. (2006). Short-term variability of dissolved trace element concentrations in the Marne and Seine rivers near Paris. Sci. Total. Environ., 367, 278-287. http://dx.doi.org/10.1016/j.scitotenv.2005.11.009

Ferreira, S. L. C., dos Santos, H. C., \& Campos, R. C. (2003). The determination of molybdenum in water and biological samples by graphite furnace atomic spectrometry after polyurethane foam column separation and preconcentration. Talanta, 61, 789-795. http://dx.doi.org/10.1016/S0039-9140(03)00378-3

Gharehbaghi, M., \& Shemirani, F. (2011). Ionic liquid-based dispersive liquid-liquid microextraction and enhanced spectrophotometric determination of molybdenum (VI) in water and plant leaves samples by FO-LADS. Food and Chemical Toxicology, 49,423-428. http://dx.doi.org/10.1016/j.fct.2010.11.017

Ghiasvand, A. R., Shadabi, S., Mohagheghzadeh, E., \& Hashemi, P. (2005). Homogeneous liquid-liquid extraction method for the selective separation and preconcentration of ultra trace molybdenum. Talanta, 66, 912-916. http://dx.doi.org/10.1016/j.talanta.2004.12.041

Gil, R. A., Pasini-Cabello, S., Takara, A., Smichowski, P., Olsina, R. A., \& Martínez, L. D. (2007). A novel on-line preconcentration method for trace molybdenum determination by USN-ICP OES with biosorption on immobilized yeast. Microchem. J., 86, 156-160. http://dx.doi.org/10.1016/j.microc.2007.02.001

Goldhaber, S. B. (2003). Trace element risk assessment: essentiality vs. toxicity. Regulatory Toxicology and Pharmacology, 38, 232-242. http://dx.doi.org/10.1016/S0273-2300(02)00020-X

Greenberg, R. R., \& Kingston, H. M. (1983). Trace element analysis of natural water samples by neutron activation analysis with chelating resin. Anal. Chem., 55, 1160-1165. http://dx.doi.org/10.1021/ac00258a041

Gutiérrez, M., \& Borrego, P. (1999). Water quality assessment of the Rio Conchos, Chihuahua, Mexico. Environ. Int'l., 25(5), 573-583. http://dx.doi.org/10.1016/S0160-4120(99)00025-2

Hall, J. O. (2012). Molybdenum. In Veterinary Toxicology; Gupta, R. C., Editor; Elsevier Inc., Amsterdam, 544-548. http://dx.doi.org/10.1016/B978-0-12-385926-6.00040-5

Hem, J. D. (2012). Study and interpretation of the chemical characteristics of natural water-US Geological Survey Water Supply Paper 2254. Retrieved from http://pubs.usgs.gov/wsp/wsp2254/pdf/section4b.pdf

Huang, S. D., Lai, W. R., \& Shih, K. Y. (1995). Direct determination of molybdenum, chromium, and manganese 
in seawater by graphite furnace atomic absorption spectrometry. Spectrochim. Acta Part B, 50, 1237-1246. http://dx.doi.org/10.1016/0584-8547(95)01342-C

Huang, X., Sillanpää, M., Duo, B., \& Gjessing, E. T. (2008). Water quality in the Tibetan plateau: metal contents of four selected rivers. Environ. Pollution, 156, 270-277. http://dx.doi.org/10.1016/j.envpol.2008.02.014

Institute of Medicine of the National Academies. (2012). Dietary Reference Intakes Tables and Application. Retrieved from http://www.iom.edu/Activities/Nutrition/SummaryDRIs/DRI-Tables.aspx.

Johannesson, K. H., Lyons, W. B., Graham, E. Y., \& Welch, K. A. (2000). Oxyanion concentrations in eastern Sierra Nevada rivers-3. Boron, molybdenum, vanadium, and tungsten. Aquatic Geochem., 6, 19-46. http://dx.doi.org/10.1023/A:1009622219482

Jones, S. R., \& McLain, B. J. (1997). US Geological Survey, Denver Colorado, Open File Report. Retrieved from http://pubs.usgs.gov/of/1997/0198/report.pdf

Karamanis, D., Stamoulis, K., Ionndes, K., \& Patiris, D. (2008). Spatial and seasonal trends of natural radioactivity and heavy metals in river waters of Epirus, Macedonia and Thessalia. Desalination, 224, 250-260. http://dx.doi.org/10.1016/j.desal.2007.07.002

Leland, H. V., \& Scudder, B. C. (1990). Trace elements in Corbicula fluminea from the San Joaquin River, California. Sci. Total Environ., 97/98, 641-672. http://dx.doi.org/10.1016/0048-9697(90)90267-X

Li, Q., Zhao, X., Guan, X., \& Liu, G. (2006). A novel method of the separation/preconcentration and determination of trace molybdenum(VI) in water samples using microcrystalline triphenylmethane loaded with salicyl fluorine. Anal. Chim. Acta, 562, 44-50. http://dx.doi.org/10.1016/j.aca.2006.01.049

Neal, C., \& Robson, A. J. (2000). A summary of river water quality data collected within the land-ocean interaction study: core data for eastern UK rivers draining to the North Sea. Sci. Total Environ., 251/252, 585-665. http://dx.doi.org/10.1016/S0048-9697(00)00397-1

Neubert, N., Heri, A. R., Voegelin, A. R., Nägler, T. F., Schlunegger, F., \& Villa, I. M. (2011). The molybdenum isotopic composition in river water: constraints from small catchments. Earth and Planet. Sci. Lett., 304, 180-190. http://dx.doi.org/10.1016/j.eps1.2011.02.001

Nriagu, J. O., Lawson, G., Wong, H. K. T., \& Azcue, J. M. (1993). A protocol for minimizing contamination in the analysis of trace metals in Great Lakes water. J. Great Lakes Res., 19(1), 175-182. http://dx.doi.org/10.1016/S0380-1330(93)71207-1

Pizarro, J., Vergara, P. M., Rodríguez, J. A., \& Valenzuela, A. M. (2010). Heavy metals in northern Chilean rivers: spatial variation and temporal trends. J. Hazard. Mater., 181, 747-754. http://dx.doi.org/10.1016/j.jhazmat.2010.05.076

Pyrzynska, K. (2007). Determination of molybdenum in environmental samples. Anal. Chim. Acta, 590, 40-48. http://dx.doi.org/10.1016/j.aca.2007.03.013

Riley, J. P., \& Taylor, D. (1968a). Chelating resins for the concentration of trace elements from seawater and their analytical use in conjunction with atomic absorption spectrophotometry. Anal. Chim. Acta, 40, 479-485. http://dx.doi.org/10.1016/S0003-2670(00)86764-1

Riley, J. P., \& Taylor, D. (1968b). The use of chelating ion exchange in the determination of molybdenum and vanadium in seawater. Anal. Chim. Acta, 41, 175-178. http://dx.doi.org/10.1016/S0003-2670(01)80379-2

Sabarudin, A., Oshima, M., Noguchi, O., \& Motomizu, S. (2007). Functionalization of chitosan with 3-nitro-4-amino benzoic acid moiety and its application to the collection/concentration of molybdenum in environmental water samples. Talanta, 73, 831-837. http://dx.doi.org/10.1016/j.talanta.2007.04.057

Shiller, A. M. (1997). Dissolved trace elements in the Mississippi River: seasonal interannual, and decadal variability. Geochim. et Cosmochim. Acta, 61(20), 4321-4330. http://dx.doi.org/10.1016/S0016-7037(97)00245-7

Smedley, P. L., Cooper, D. M., Lapworth, D. J., \& Ander, E. L. (2008). Molybdenum in British drinking water: a review of sources and occurrence and a reconnaissance survey of concentrations. British Geological Survey Groundwater Resources Programme Open Report OR/08/051. Retrieved from http://nora.nerc.ac.uk/3732/1/OR08051.pdf

Sun, Y. C., Yang, J. Y., \& Tzeng, S. R. (1999). Rapid determination of Molybdate in natural waters by coprecipitation and neutron activation analysis. Analyst, 124, 421-424. http://dx.doi.org/10.1039/a809596e 
Sung, Y. H., Liu, Z. S., \& Huang, S. D. (1997). Use of muromac A-1 chelating resin for the determination of copper and molybdenum in seawater by atomic absorption with on-line preconcentration. Spectrochim. Acta Part B, 52, 755-764. http://dx.doi.org/10.1016/S0584-8547(96)01630-8

Trocine, R. P., \& Trefry, J. H. (1996). Metal concentrations in sediment, water and clams from the Indian River $\begin{array}{lllll}\text { Lagoon, Florida. } & \text { Marine Pollution }\end{array}$ http://dx.doi.org/10.1016/0025-326X(96)00071-9

Turnlund, J. R., Keyes, W. R., Peiffer, G. L., \& Chiang, G. (1995). Molybdenum absorption, excretion, and retention studied with stable isotopes in young men during depletion and repletion. Am. J. Clin. Nutr., 61, 1102-1109.

United States Environmental Protection Agency (USEPA). (2012). Great lakes areas of concern: Rouge River. Retrieved from http://glc.org/raptest/rougriv.html

Wang, D., \& Sañudo-Wilhelmy, S. A. (2008). Development of an analytical protocol for the determination of $\mathrm{V}(\mathrm{IV})$ and $\mathrm{V}(\mathrm{V})$ in seawater: application to coastal environments. Marine Chemistry, 112, 72-80. http://dx.doi.org/10.1016/j.marchem.2008.05.011

Zimmer, W., \& Mendel, R. (1999). Molybdenum metabolism in plants. Plant Biology, 1, 160-168. http://dx.doi.org/10.1111/j.1438-8677.1999.tb00239.x 